\title{
LAND POLICY IN LATVIA: IMPLEMENTATION AND EVALUATION OF RESULTS
}

Velta PARSOVA, Faculty of Rural Engineering, Latvia University of Agriculture, Akademijas st.19, Jelgava, LV-3001, Latvia, velta@parsova.lv (corresponding author)

Edvins KAPOSTINS, Spatial Planning Department, The Ministry of Environmental Protection and Regional Development, Latvia, edvins.kapostins@varam.gov.lv

\begin{abstract}
The use and protection of land are essential for the development and existence of any country. Therefore it is necessary to develop a national policy for rational administration and management of the land, because at least $20 \%$ of Gross Domestic Product (GDP) can be obtained from the land, real property and construction. One of the main aims of the Sustainable Development Strategy of the European Union is environmental protection, at the same time maintaining capacity of land to support life in all its diversity, bearing in mind that natural resources are limited. The challenge is to ensure environmental protection and improvement of the environment, to promote sustainable production and consumption in order to break the link between economic growth and environmental degradation. This can be achieved by improving the effectiveness of management of resources as well as avoiding over-exploitation of renewable or non-renewable natural resources and stopping the loss of biodiversity. In 2008 in Latvia the Land Policy Guidelines for the time period till 2014 were approved defining the national policy in land use as well as determining activities for promotion of sustainable land use. The article analyzes the problems of land use, the aims set in the land policy and the achieved results as well as gives recommendations for further development of the land policy.
\end{abstract}

Keywords: completion of land reform, land policy, land use, unused agricultural land.

\section{INTRODUCTION}

In beginning of the 90-ies of the last century the Parliament of Latvia accepted the resolution on the agrarian reform and the laws on the land reform both in rural and urban areas. At that time the purpose of the land reform was to reorganize legal, social and economic relations of land use and land ownership in towns and rural areas in the course of gradual privatization of the land for the facilitation of restoration of a traditional style of life, protection and economic use of nature and other resources, expansion of production of high quality agricultural products. However, only the change of the legal basis of land use did not lead to the desired results that could ensure protection of land resources and their rational and economic use, preservation and improvement of soil fertility, as well as the development of urban areas in compliance with the interests of society. This was the basis of the decision to develop and implement the land policy.

Land policy is a framework for determining, how the land should be used and preserved in order to meet social and economic objectives (UN ECE, 2005). In the context of the Land Policy Guidelines, the land mainly is considered as:

- $\quad$ resource for use and development;

- $\quad$ an object of rights;

- $\quad$ an object of value (Figure 1).

These aspects of land policy are closely interrelated, and significant changes in any of these aspects can influence others. For example, the value of land can be affected by land use and vice versa, permitted use of land affects the value of land, the registration of property rights may affect administration of real property tax (Williamson et al, 2010). Public and private interests and needs are taken into account when analyzing the mentioned trends of land policy.

Implementation of land policy requires a multi-disciplinary approach and an effective legal framework (UN ECE, 2005). The Land Policy Guidelines from the point of view of "land as resource" consider land not only as the means of production comprising land use and protection, but also as a place (space) for the development, including its use and development planning, building and landscape design. As regards the aspect"land as a legal object", land is analyzed in relation to the registration of rights and information about land. Also, the guidelines consider land as an object of value meaning the development of real property market and the influence of taxes on land use.

The object of the research: results of the existing land policy in Latvia. 


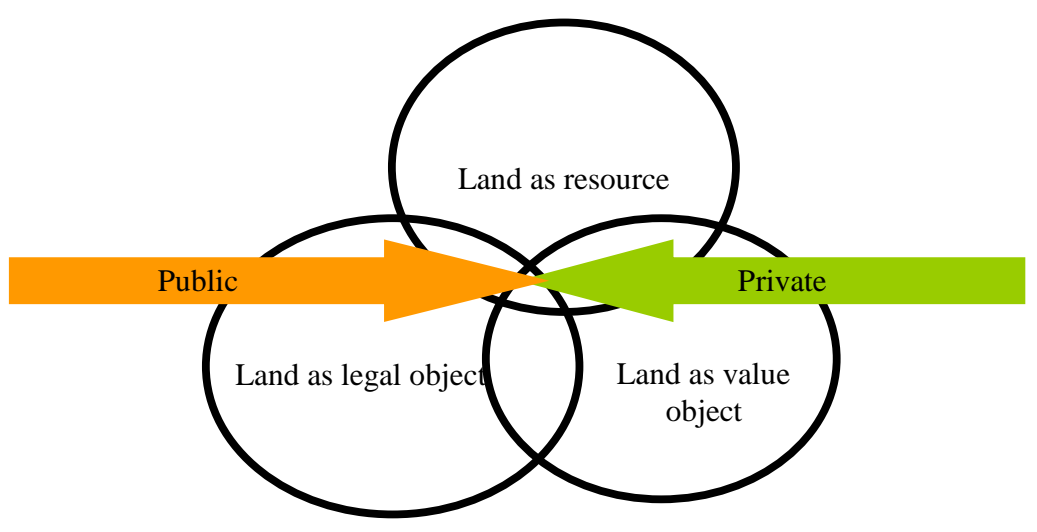

Figure 1. Land policy framework

The aim of the research: to carry out the analysis of main trends of development for provision of sustainable use of the land within the framework of the Land Policy Guidelines approved in 2008.

Tasks of the research: to characterize the information on identified problems in land use, on the land policy objectives and achieved results, as well as to give recommendations for future development of the land policy.

\section{METHODOLOGY OF THE RESEARCH}

The methods of comparative, analytical, statistical and logical analysis and historical research for the investigation of the years 2008-2014 were used. In addition, the research and proposals made in ad hoc working groups, with the participation of the authors, devoted to the analysis of the land policy issues and preparation of proposals on setting up and implementation of the land policy measures, were used. Rules and regulations of the Cabinet of Ministers, the professional literature published in Latvia and abroad were studied. The research performed at the Department of Land Management and Geodesy of the Latvia University of Agriculture was summarized and the activities of the Ministry of Environmental Protection and Regional Development of Latvia in the development and implementation of the land policy were analysed by the authors.

\section{RESULTS}

\section{Identified Problems for Development of Land Policy Guidelines}

Various processes and their consequences which caused problems were identified depending on what aspect of land was analyzed - either land as resource, an object of rights or an object of value. The assessment of the situation in Latvia identified the following main problems of the land policy:

- $\quad$ irrational and inefficient use of land;

- the lengthy process of the land reform leading to drawbacks in property rights arrangement as well as the insufficient information about the land and related processes.

Irrational or inefficient use of land leads to and facilitates land degradation. The main land degradation processes in Latvia are the following:

- $\quad$ soil degradation (reduction of organic matter, increase of soil acidity, soil erosion);

- land abandonment (unused agricultural land) and overgrowing of agricultural land;

- coastal erosion on the coast of the Baltic Sea and the Gulf of Riga;

- the paludification of land due to insufficient maintenance of the drainage system.

One of the processes enhancing land degradation is the development of new settlements (villages) on agricultural land around large towns. It was especially active during the period from 2006 to 2008 . In many cases this process was relatively chaotic and uncontrolled. This uncontrolled growth increased energy consumption, raised the cost of infrastructure and services, and had negative effects on the quality of the environment (European Environment ..., 2010; Demetriou, 2013). This was due to the development of the real property market "bubble" when plans were developed to divide agriculture land into smaller building plots. The consequences can be seen even today, when agriculture land has been divided into plots for building housing, but construction has never started or has started only in some parts. As the survey of agricultural land shows, there is a large proportion of unused land around Riga where the above mentioned process was especially active.

In climatic conditions of Latvia where the amount of precipitation exceeds the total evaporation, land amelioration, which is necessary for $90 \%$ of the territory of agriculture land, should be one of the measures preventing land paludification. However, drainage systems on large areas, installed during the Soviet period, have deteriorated or out of order, since they have not been properly maintained therefore it is one of the reasons why the area of wetland have increased. 


\section{Land policy implementation trends}

The Land Policy Guidelines provided several directions of actions to ensure sustainable use of the land as unique natural resource, to promote the rational and efficient land use, to create a stable legal, informative and economic environment. To achieve this goal, the guidelines defined objectives and directions of action:

- ensuring of diverse land management development and use of unused agricultural land;

- ensuring of conservation and rational use of the land and other natural resources;

- improvement of the system of territory planning, development of sustainable settlement structure;

- completion of the land reform, arrangement of land ownership and its development;

- simplification and modernization of ownership registration system.

The development of land management should be viewed in relation to measures implemented in the framework of the Rural Development Programme. For example, the number of farms (holdings) involved in real agricultural activity and production of agriculture products has increased. The proportion of such holdings compared with 2009 has increased by $13 \%$. Besides, land management depends on the knowledge and experience of landowners and users. In order to improve knowledge of landowners, the rural advisory system was established in Latvia ensuring availability of services offered by rural development specialists. Services are available to assist clients (farmers, foresters, entrepreneurs, etc.) as close as possible from their place of residence ensuring knowledge transfer, activities of exchange of experience and information.

The surface and structure of land are strictly connected with the topography of the region but at the same time the structure of the land depends on land use and its efficiency (Bansky, 2013). The Cadastre Information System of State Land Service of Latvia shows that since 2008 the percentage of agricultural land has decreased by $1.2 \%$, and now the area of agricultural land is $36.7 \%$ of the total area of Latvia. In comparison with 1940, agricultural land accounted for $57.5 \%$ of the total area of Latvia. This change can be explained to some extent by overgrowing of agricultural land and its transformation into forests, because during the mentioned period the total area of forest land has increased by $1.5 \%$ and now it accounts for $47.0 \%$ of the total area of Latvia. As regards agricultural land now, 51 thousand ha are considered to be overgrown. This trend can be compared with other European countries, because new arable land and permanent crops required an additional $5.4 \mathrm{~km}^{2}$ of land. During the same period of $8.3 \mathrm{~km}^{2}$ of this land was lost or changed to other land uses. Part of agriculture land decline happened when marginal farmlands were abandoned and some were forested (European Environment ..., 2010).

In the Rural Development Plan of National Strategy of Latvia for the period 2007-2013, facilitation of production of renewable energy sources, especially biomass, was identified as one of the priorities. The government financed activities which promoted production and use of renewable energy. During this period it was possible to get the EU structural funds for energy production from agricultural and forestry biomass for the purpose of the implementation of the Rural Development Plan, thus promoting the use of the land for production of non-food products. It should be noted that such a solution can be evaluated as controversial, because agricultural land is used more and more for vegetable crops, which serves for energy production instead of food. There is an intense global competition for the resources requiring more efficient land use to meet the needs of society (VOLANTE ..., 2015).

To facilitate more efficient use of unused agricultural land and to avoid its degradation (overgrowth), additional rate of real property tax on unused agricultural land was introduced. The data of the survey made by the Rural Support Service show that unused agricultural land in 2014 was 294 thousand ha accounting for 12. \% of the total agricultural land. According to the research conducted by the scientists of the Latvia University of Agriculture, the qualitative assessment of $62.9 \%$ of unused land is less than 25 points. It shows that the land, which has become unused, mostly is not effective for agricultural production (Pilvere, 2012). The use of agricultural land should be viewed in relation to the development of the agricultural sector as a whole. In recent years there has been a growing demand for agricultural land. It is due to an increasing proportion of productive farms and the demand for the land, encouraged by the Credit Programme for Agricultural Land Purchase started in Latvia implementing measures that support the purchase of agricultural land. This programme provides the support to agricultural entrepreneurs or to young farmers to buy the land, if they have already started or are planning to start economic activities. The maximum amount of available loan is 142 thousand EUR for the time period of 20 years.

In Latvia in 2014 the price of agricultural land in average increased by $12 \%$, but the most rapid increasing of prices was observed in Latgale and Kurzeme - up to $35 \%$. An increasing demand for agricultural land is one of the reasons why the area of unused land has decreased by 22 thousand ha since 2010.

\section{Provision of conservation and rational use of the land and other natural resources}

The legislation on land privatization restricted purchasing of agricultural and forest land by foreigners, but these restrictions ended on $1^{\text {st }}$ of May, 2014. On $3^{\text {rd }}$ of July, 2014 the Parliament adopted amendments, which determined the procedures of transactions with agricultural land. Thereby a mechanism of market regulation was introduced, the aim of which was to ensure conservation of land resources at disposal of people of Latvia. These amendments provide: if an area of agricultural land in the land parcel is more than 5 hectares, it can be bought by a person with relevant education in agriculture, with prior experience in land use as well as if the person confirms in the written form that the purchased land will be used for agricultural activities. Transactions with agricultural land are under the supervision of commissions of a local municipality. The essence of restrictions is the fact that agricultural land should be used for agricultural production thus promoting rational use of agricultural land. 
To save the most valuable agricultural and forest land, The Law on Land Administration, adopted in 2014, defined conditions and principles of land use and protection. One of such conditions is preservation of valuable agricultural land, limiting its fragmentation and change of land use categories (Zemes pārvaldības ..., 2005).

With the aim to preserve especially valuable agricultural land, the Regulations of the Cabinet of Ministers concerning agricultural territories of national significance were accepted. There is a legal provision determining that agricultural territories of national significance include the land with the qualitative assessment higher than 60 points and the area of more than 50 hectares. These territories are located in five administrative units of Zemgale. Regulations prescribe restrictions according to subdivision of land parcels and transformation to other types of land use categories.

The Guidelines stated that in the period 2008-2014 the area of agricultural territories of national significance (except agricultural polders) should not decrease by more than $5 \%$. Unfortunately, the state information system does not collect data about the mentioned territories, therefore the survey of local municipalities was carried out. The results of the survey show that since 2008 the total area of especially valuable land has not decreased.

The average qualitative assessment of the land in Latvia is 38 points (Boruks, 2001). This indicator is calculated using data of soil mapping and land quality assessment, but they are more than thirty years old. Unfortunately, now in Latvia information on the current land quality assessment does not exist. However, taking into account the proportion of unused agricultural land and the fact that drainage systems have not been reconstructed, it can be expected that average qualitative assessment of the land in Latvia could be reduced.

\section{Improvement of system of territory planning, development of sustainable settlement structure}

Spatial planning is critical for delivering economic, social un environmental benefits by promoting prudent use of land and natural resources for development (UN ECE, 2008). For improvement of spatial planning system Law on Territorial Development Planning was adopted in 2011, which provided an integrated approach to ensure harmonization of economic, cultural, social and environmental aspects of land use, mutual coordination of interests of individual sectors and harmonization of priorities of spatial development on all planning levels (Teritorijas attīstības ..., 2011).

"General Regulations on Spatial Planning, Use and Building" developed on the basis of the mentioned law is one of the basic documents for development of spatial plans in municipalities which defines the requirements of all kind of territory planning and land use.

To reduce the expansion of urban territories and development of new building on productive land, the Law on Land Administration includes regulations of land use and protection, including rules that new building areas should be planned on degraded land and areas convertible to building areas, while transformation of agriculture and forestry land should be planned on the area with the lowest land quality assessment or the location and configuration of which are not suitable for further use in agriculture or forestry. Requirements for planning of urban territories are defined there providing that new territories of complex building should be planned within existing boundaries of cities, towns and villages. Planning new villages or expanding territories of existing urban areas, easy access to them and engineering supply facilities as well as public open space, including nature and green zone territories available for public, should be provided.

\section{Completion of land reform, arrangement of land ownership and its development}

The land in Guidelines was viewed as an object of rights and value. Land use partly is determined by property rights and partly by its value (Ministry ..., 2009). Similarly, the value is also affected by available information on the land and its legal status. Therefore one of the objectives of the land policy is development of effective and stable legal, economic and informational environment (Office for ..., 1999).

According to legislative acts, the land reform is completed if the Cabinet of Ministers makes a decision on completion of the land reform in each particular municipality (the total number of municipalities is 119). At the end of 2014 the first decision was made on completion of the land reform in Olaine municipality. Since the beginning of 2015 such decisions have already been prepared for more than 42 municipalities of cities and towns and for more than 34 rural municipalities. Thus, it can be planned that the land reform, which goes on for more than 20 years, will be completed by the end of 2015. Regardless of the fact that the land reform is going to be completed, not all land properties have cadastrally surveyed boundaries, especially in cases of restitution of property rights or if land cadastral surveying should be done from the state budget. Cadastrally surveyed boundaries account for $84 \%$ of the total land area. Proportion of land properties registered in the Land Register (Landbook) has increased from $65 \%$ in 2008 to $80 \%$ in 2015. Although several amendments to the legislative acts have been made in order to reduce the complexity of the registration process of property rights, there are still many land properties, property rights of which are not registered. It affects negatively the future use of these properties. Any asset whose economic and social aspects are not fixed in a formal property system is extremely hard to move in the market (De Soto, 2000).

The whole area of dry land of Latvia is registered in the cadastre information system, consequently, a full set of information about all cadastral objects and their indicators is available now.

\section{Simplification and modernization of ownership registration system}

The number of days and procedures necessary for registration of property rights in all countries of the world is indicated in the website www.doingbuisness.org. Changes related to the registration process of property rights in Latvia comparing the years 2008 and 2014 are significant, however, one case of registration of property rights still requires 5 procedures within 18 days. The forecasted in the Guidelines figures -3 procedures within 11 days - have not been achieved yet. 
The amendments to the Real Property State Cadastre Law, the Law "On Registration of Real Property in Landbook" and Land Registration Law have been adopted, significantly simplifying the process of property registration, reducing the administrative burden (Nekustamā ..., 2005). The amount of information submitted by the Cadastre Information System to the computerized Landbook through online data transmission has increased. The above mentioned amendments state that a judge of a particular Landbook department makes a decision regarding the area of land parcel and other information of land boundary plan or cadastral survey file on the basis of the Cadastre Information System. Land under public transport infrastructures can be recorded in the Landbook without a cadastral survey, thus the property rights over this land can be fixed on the basis of the Cadastre Information System.

\section{CONCLUSIONS}

In Latvia the area of unused agricultural land has reduced due to the increasing demand in land resources and activities within the Rural Development Programme. This process is also positively affected by the changes in the Law "On Real Property Tax", raising the rate of tax on unused agricultural land. In addition, building on agricultural land has reduced due to the real property market crisis as well as due to the development of a more efficient planning system.

The following results have been achieved in the framework of the land policy in Latvia:

- legislative acts have been improved for preservation of especially valuable land;

- the functioning and effective system of spatial planning at the national, regional and local level have been developed;

- the information system of admistrative territory planning has been developed, which will allow more effective planning process in the future;

- the rural landscape is recognized as the value, which should be preserved, planned and maintained; several initiatives have been started to develop local landscape protection plans;

- administrative burden in sphere of the registration of real property rights has reduced due to data exchange among different information systems and implementation of e-services;

- the system of land expropriation for public purposes for fair compensation has been improved.

Although many measures of the Land Policy Guidelines have been implemented, there are several issues that should be solved in the next planning period in order to ensure sustainable land use and land protection. It is necessary to define strategic objectives in land use as well as methods of solution of issues, preparing actions and measures in order to:

- $\quad$ prevent reduction of the area of agricultural land;

- $\quad$ reduce the area of inefficiently used land, including degradated territories, and promote its best possible use;

- $\quad$ ensure protection of soil and promote preservation of biodiversity;

- $\quad$ promote the use of the land potential for prevention of climate changes and the use of the land as natural capital for the development of ecosystem services as well as in preservation of cultural and landscape values;

- ensure updating of geospatial information, accessibility, quality and interoperability with regard to information about the land and its management processes;

- promote land consolidation, including issues on further use and maintenance of the land which remains at disposal of landowners after construction of roads;

- establish the Land Compensation Fund, which could be the basis for land exchange if it is necessary for the development of the state or municipal infrastructure or other objects.

\section{REFERENSES}

1. Boruks, A. 2001. Zemes izmantošana un kadastrs Latvijā, LLU and SLS, Riga. (In Latvian)

2. Banski, J. Garcia-Blanco, G. 2013. European Land Use Patterns, Polish Gographical Society, Warszawa.

3. Demetriou, D. 2013. The development of integrated planning and decision support system (IPDSS) for land consolidation, Printforce, the Netherlands.

4. De Soto, H. 2000. The Mystery of Capital: Why Capitalism Triumphs in the West and Fails Everywhere Else, Basic Books, New York

5. European Environment Agency, 2010. The European Environment - State and Outlook 2010, Publications Office of the European Union, Luxemburg.

6. Ministry of Regional Development and Local Government, 2009. The Development Conception of Spatial planning system. Available at: http://www.raplm.gov.lv/uploads/filedir/telpiska\%20planosana/2009/RAPLMkonc_020609_TPS.pdf (accessed on 10/09/2014)

7. Nekustamā īpašuma valsts kadastra likums, 2005. http://likumi.lv/doc.php?id=124247 (accessed on 23/05/2015)

8. Office for Official Publications of the European Community, 1999. European Spatial Development Perspective Towards Balanced and Sustainable Developments of the Territory of the European Union, European Commision, Luxemburg

9. Pilvere, I. 2012. Lauksaimniecības zemes izmantošanas efektivitātes un iespēju novērtējums, Latvijas Valsts augḷkopības institūts, Rīga. (In Latvian).

10. Teritorijas attīstības plānošanas likums, 2011. http://likumi.lv/doc.php?id=238807 (accessed on 23/05/2015). (In Latvian)

11. Zemes, mana, tava, mūsu. 2002. Valsts zemes dienests, Riga. (In Latvian) 
12. UN Economic Commission for Europe, 2005. Land administration in the UNECE region: Development trends and main principles, United Nations, New York and Geneva

13. UN Economic Commission for Europe, 2008. Spatial Planning - Key Instrument for Development and Effect of Governance, United Nations, New York and Geneva

14. VOLANTE consortium, 2015. The Volante Road Map Towards Sustainable Land Resource Management in Europe, Available at: www.volante-project.eu (accessed on 12/05/2014)

15. Williamson I., Enemark S., Wallace J., Rajabifard A. 2010. Land Administration for Sustainable Development, ESRI Press Academic, California

16. Zemes pārvaldības likums, 2014. http://likumi.lv/doc.php?id=270317 (accessed on 23/05/2015). (In Latvian) 